\title{
Rearranged Sesquiterpenes and Branched Polyketides Produced by the Endophyte Camarops sp.
}

\author{
Juliana R. Gubiani ${ }^{\mathrm{a}, *}$, Cláudio R. Nogueira ${ }^{\mathrm{b}}$, Marcos D.P. Pereirac ${ }^{\mathrm{c}}$, Maria C.M. Young ${ }^{\mathrm{d}}$, \\ Paulo M.P. Ferreira ${ }^{e}$, Manoel O. de Moraes $^{f}$, Cláudia Pessoa ${ }^{f}$, Vanderlan S. Bolzani ${ }^{\mathrm{a}}$, \\ Angela R. Araujo ${ }^{\mathrm{a}, *}$
}

\author{
a Nucleus of Bioassays, Biosynthesis and Ecophysiology of Natural Products (NuBBE), Department of Organic Chemistry, Institute of Chemistry, São Paulo State \\ University, 14800-900 Araraquara, SP, Brazil \\ ${ }^{\mathrm{b}}$ Faculty of Science and Technology, Federal University of Grande Dourados, 79804-970 Dourados, MS, Brazil \\ ${ }^{\mathrm{c}}$ Department of Organic Chemistry, Institute of Chemistry, São Paulo State University, 14800-900 Araraquara, SP, Brazil \\ ${ }^{\mathrm{d}}$ Physiology and Plant Biochemistry Section, Botanical Institute, 01061-970 São Paulo, SP, Brazil \\ e Department of Biophysics and Physiology, Federal University of Piauí, 64049-550 Teresina, PI, Brazil \\ ${ }^{\mathrm{f}}$ Department of Physiology and Pharmacology, Faculty of Medicine, Federal University of Ceará, 60430-270 Fortaleza, CE, Brazil
}

\section{A R T I C LE IN F O}

\section{Article history:}

Received 28 May 2016

Received in revised form 5 August 2016

Accepted 8 August 2016

Available online 13 August 2016

Keywords:

Rearranged sesquiterpenes

Branched polyketides

Endophytic fungus

Camarops sp.

Alibertia macrophylla

\section{A B S T R A C T}

Two rearranged sesquiterpenes, 3,5,9-trihydroxy presilphiperfolane (1) and 4-deoxy-10-oxodihydrobotrydial (2), and two branched polyketides, 4-((E)-pent-1-enyl)-3-((1'S,2'S)-1',2'-dihydroxybut-3-enyl)$5 \mathrm{H}$-furan-2-one (3) and (2E,4R)-2,4-dimethylnon-2-enoic acid (4), along with three known compounds $(2 E, 4 S)$-2,4-dimethyloct-2-enoic acid (5), xylarenone $C(\mathbf{6})$, xylarenone D (7), were isolated from solid substrate cultures of Camarops sp., an endophyte of Alibertia macrophylla (Rubiaceae). The structures were established by means of NMR and HRESIMS analyses. The absolute stereochemistry of 3 was determined through the application of the modified Mosher method. Compounds 6 and 7 exhibited cytotoxic activity against leukemia (HL-60), melanoma (MDA/MB-435), colon (HCT-8) and glioblastoma (SF-295) human tumor lines, while compounds 4-7 presented acetylcholinesterase inhibition.

(c) 2016 Phytochemical Society of Europe. Published by Elsevier Ltd. All rights reserved.

\section{Introduction}

Sesquiterpenes and polyketides are known to be secondary metabolites produced by a number of endophytic fungi (Collado et al., 2007). Two unrelated families of sesquiterpenoids include the botryanes and the presilphiperfolanes. Botryanes were first isolated from cultures of the fungal plant pathogen Botrytis cinerea which grows as a grey mold in a wide range of commercial crops, causing serious economic losses. Botrydial and dihydrobotrydial produced by $B$. cinerea are known to be responsible for typical plant lesions through the phytopathogenic fungus and are essentially found to play an important role in the pathogenicity of B. cinerea. Botrydial tends to exhibit phytotoxic activity in vitro and in planta on tobacco leaves. Furthermore, Botrydial is also said to display antibiotic activity against Bacilus subtilis and Phytium debaryanum, while presenting potent cytotoxic activity against tumoral and

\footnotetext{
* Corresponding authors.

E-mail addresses: julianagubiani@yahoo.com.br (J.R. Gubiani), araujoar@iq.unesp.br (A.R. Araujo).
}

non-tumoral cells (Collado et al., 2007; Daoubi et al., 2006; Reino et al., 2003).

Presilphiperfolane or probotryane sesquiterpenes were originally isolated from the Californian coastal succulent plant Eriophyllum staechadifolium, and subsequently from Senecio anteuphorbium, S. imparipinnatus, S. runcinifolius, Ursina nana, S. coronatus and $S$. hadiensis. More recently, presilphiperfolanes have also been obtained from cultures of endophytic fungi, raising plausible concerns regarding the actual source of such terpenes in plants. Presilphiperfolanes show antifeedant activity against the chrysomelid Leptinotarsa decemlineata and the aphid Diuraphis noxia (Collado et al., 2007; Durán-Patrón et al., 2001).

Botryanes and presilphiperfolanes differing in the oxidation level of C-10 and C-15 are commonly found among microorganisms. A number of carboxylic acids and lactone derivatives of these compounds have also been isolated alongside hemiketals connected at C-10/C-15. Botryane metabolites have been reported as products of botrydial dehydration and of 10-oxodihydrobotrydial. The putative diene precursor may undergo dehydrogenation so as to obtain aromatic metabolites, while electrocyclic ringopening is known to give rise to triene derivatives and further 
oxidized products. Biosynthetic experiments with $B$. cinerea suggested the formation of botryanes and probotryanes from presilphiperfolane precursors (Collado et al., 2007; Durán-Patrón et al., 2001).

Butenolide or furanone polyketides are widely known to be among natural products, and are found to exhibit an array of biological activities (Ali et al., 2015). Butenolides are also versatile synthetic building blocks for the construction of more complex molecular scaffolds. Thus, facile access to butenolides is seen to be of considerable significance when it comes to organic and medicinal chemistry synthesis (Ali et al., 2015; Mao and Zhu, 2015).

Our core objective in this present work lied in isolating and identifying the new rel-( $1 S, 3 S, 4 S, 5 R, 7 S, 9 S)-3,5,9$-trihydroxy presilphiperfolane (1), rel-(1S,2S,5R,8R,9R)-4-deoxy-10-oxodihydrobotrydial (2), 4-((E)-pent-1-enyl)-3-((1'S,2'S)-1',2'-dihydroxybut3-enyl)-5H-furan-2-one (3) and (2E,4R)-2,4-dimethylnon-2-enoic acid (4) (Fig. 1) produced by Camarops sp. strain grown in solid medium. The isolation of the known metabolites $(2 E, 4 S)-2,4-$ dimethyloct-2-enoic acid (5), xylarenone C (6) and D (7) is also reported. In addition, the cytotoxicity and cholinesterase inhibitory activities for 3-7 are also presented.

\section{Results and discussion}

HRESIMS analysis of $\mathbf{1}$ showed a quasi-molecular ion peak $[2 \mathrm{M}+\mathrm{Na}]^{+}$at $\mathrm{m} / \mathrm{z} 531.3869$, corresponding to the formula $\mathrm{C}_{15} \mathrm{H}_{26} \mathrm{O}_{3}$, with three degrees of unsaturation. The IR (3375 and $2927 \mathrm{~cm}^{-1}$ ) spectrum showed the presence of $\mathrm{C}-\mathrm{H}$ and hydroxyl functional groups.

Analysis of ${ }^{1} \mathrm{H},{ }^{13} \mathrm{C}$ NMR and HSQC spectra of $\mathbf{1}$ (Table 1) indicated the presence of five $\mathrm{sp}^{3}$ methine, two of which are oxygenated, three methylene, four methyl groups and three quaternary carbons with one being oxygenated.

Analysis of COSY data led to the assignment of the spin-system depicted in boldface in Fig. 2. Both methyl groups $\mathrm{CH}_{3}-13(\delta 0.92)$ and $\mathrm{CH}_{3}-14(\delta$ 1.03) presented correlations in $\mathrm{HMBC}$ with each other, indicating a gem-dimethyl group.

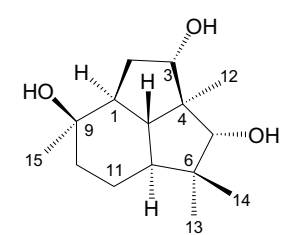

1

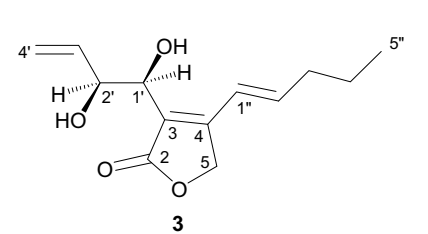

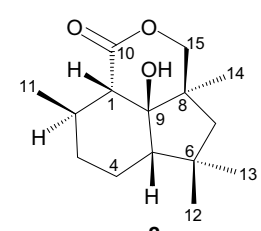
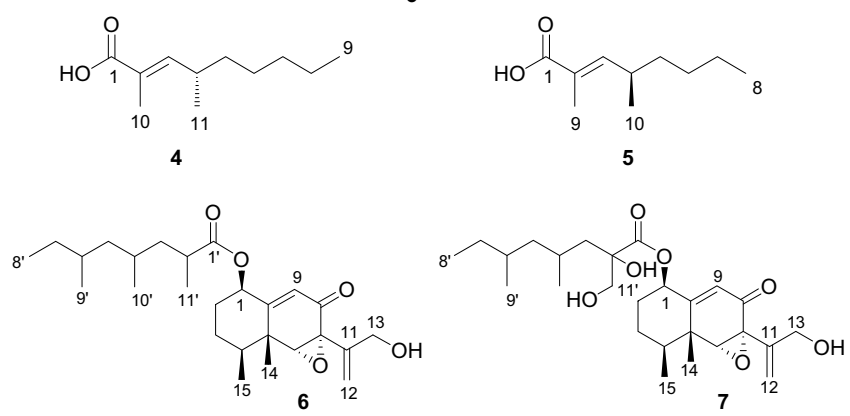

The key HMBC correlations of $\mathrm{H}-5 \leftrightarrow \mathrm{C}-7 / \mathrm{C}-8 / \mathrm{C}-14 / \mathrm{C}-13, \mathrm{H}-$ $3 \leftrightarrow \mathrm{C}-12 / \mathrm{C}-8$ and $\mathrm{H}-1 \leftrightarrow \mathrm{C}-7$ as shown in Fig. 2 enabled the connection of the two cyclopentane rings and the hexane ring in Fig. 1. The HMBC correlations observed for $\mathrm{H}-12 \leftrightarrow \mathrm{C}-3$ and $\mathrm{H}-$ $15 \leftrightarrow \mathrm{C}-10$ indicated $\mathrm{CH}_{3}-12$ and $\mathrm{CH}_{3}-15$ as the location of these methyl groups.

The relative stereochemistry of $\mathbf{1}$ was determined through analysis of the coupling constants in its ${ }^{1} \mathrm{H}$ NMR spectrum and by means of a 1D NOESY experiment analysis (Fig. 4). Coupling constants of $\mathrm{H}-8\left(\delta_{\mathrm{H}} 1.28, d d, 8.6\right.$ and $\left.8.6 \mathrm{~Hz}\right)$ indicated a trans relationship with both $\mathrm{H}-1$ and $\mathrm{H}-7$. The NOE experiment showed dipolar couplings between $\mathrm{CH}_{3}-14$ and $\mathrm{H}-8$ and $\mathrm{H}-5$, as well as between $\mathrm{CH}_{3}-12$ and $\mathrm{CH}_{3}-15$. This enabled the assigning of the complete relative stereochemistry of $\mathbf{1}$ as rel-(1S,3S,4S,5R,7S,9S)3,5,9-trihydroxy presilphiperfolane.

HRESIMS analysis of compound 2 showed a pseudomolecular ion peak $[\mathrm{M}-\mathrm{H}]^{-}$at $\mathrm{m} / \mathrm{z} 251.1623$, corresponding to the formula $\mathrm{C}_{15} \mathrm{H}_{24} \mathrm{O}_{3}$ with four degrees of unsaturation. The IR (3408 and $1699 \mathrm{~cm}^{-1}$ ) spectrum showed the presence of hydroxyl and carbonyl groups, as confirmed by the ${ }^{13} \mathrm{C}$ NMR spectrum (Table 1 ).

Analysis of ${ }^{1} \mathrm{H},{ }^{13} \mathrm{C}$ and HSQC NMR spectra of $\mathbf{2}$ (Table 1 ) indicated the presence of one oxymethylene, three methine, three methylene and four methyl groups as well as one oxygenated carbon and one ester or lactone carbonyl $\left(\delta_{C} 172,1\right)$. Analysis of COSY data prompted the assignment of spin-system one as depicted in boldface in Fig. 2. As in compound 1, both methyl groups $\mathrm{CH}_{3}-12(\delta 1.25)$ and $\mathrm{CH}_{3}-13(\delta 1.13)$ exhibited correlations in HMBC with each other, indicating a gem-dimethyl group.

The HMBC correlations of $\mathrm{H}-1 \leftrightarrow \mathrm{C}-2 / \mathrm{C}-5 / \mathrm{C}-9$, and $\mathrm{H}-5 \leftrightarrow \mathrm{C}-8 / \mathrm{C}-$ 13 , jointly with the main correlation of $\mathrm{H}-15 \leftrightarrow \mathrm{C}-9 / \mathrm{C}-10\left(\delta_{C} 172.1\right)$ pointed out the fact that the structure of $\mathbf{2}$ is closely related to those of compounds 10-oxodihydrobotrydial (Collado et al., 1995) and 4-deacetyl-10-oxodihydrobotrydial (Yuan et al., 2009) with the difference being that 2 lacks oxygenation at C-4.

The relative stereochemistry of $\mathbf{2}$ was established via its coupling constants in the ${ }^{1} \mathrm{H}$ NMR spectrum. For methine $\mathrm{H}-1\left[\delta_{\mathrm{H}}\right.$ $2.27(d, J=11.5 \mathrm{~Hz})]$, a trans relationship with $\mathrm{H}-2$ was assigned. In addition, 1D NOEDiff analysis of $\mathbf{2}$ presented dipolar couplings between $\mathrm{CH}_{3}-11$ and $\mathrm{H}-5, \mathrm{H}-5$ with $\mathrm{H}-12$, and $\mathrm{H}-13$ with $\mathrm{H}-14$. Hence, the complete relative stereochemistry of $\mathbf{2}$ was determined as rel-(1S,2S,5R,8R,9R)-4-deoxy-10-oxodihydrobotrydial.

HRESIMS analysis of compound 3 showed a quasi-molecular ion peak $[\mathrm{M}+\mathrm{Na}]^{+}$at $\mathrm{m} / \mathrm{z} 261.1070$ associated with the formula $\mathrm{C}_{13} \mathrm{H}_{18} \mathrm{O}_{4}$, corresponding to five degrees of unsaturation. $\mathrm{UV}$ ( $\lambda_{\max }$ at $266 \mathrm{~nm}$ ) and IR (3431 and $1735 \mathrm{~cm}^{-1}$ ) spectra showed the presence of a hydroxyl and a carbonyl group, as similarly observed in the ${ }^{13} \mathrm{C}$ NMR spectrum.

Analysis of ${ }^{1} \mathrm{H},{ }^{13} \mathrm{C}$ and HSQC NMR spectra of 3 (Table 1 ) indicated the presence of three $\mathrm{sp}^{2}$ methine, two $\mathrm{sp}^{3}$ oxymethine, one $\mathrm{sp}^{3}$ oximethylene, four $\mathrm{sp}^{3}$ methylene, one methyl groups and one carbonyl at $\delta_{\mathrm{C}} 175.4$.

The presence of an $n$-pentenyl and but-3-ene-1',2'-diol moiety was observed in the COSY spectrum of $\mathbf{3}$ and confirmed through the correlations observed in $\mathrm{HMBC}$ of $\mathrm{H}-5^{\prime \prime}$ and $\mathrm{H}-1^{\prime \prime}$ to $\mathrm{C}-3^{\prime \prime}$ as well as $\mathrm{H}-1^{\prime} \leftrightarrow \mathrm{C}-3^{\prime}$ and $\mathrm{H}-4^{\prime \prime} \leftrightarrow \mathrm{C}-2$ as depicted in Fig. 2. The trans configuration at $\mathrm{C}-1^{\prime \prime} / \mathrm{C}-2^{\prime \prime}$ was established by the coupling constant of $16.0 \mathrm{~Hz}$ between $\mathrm{H}-1^{\prime \prime}$ and $\mathrm{H}-2^{\prime \prime}$. The unsaturated lactone ring was evident owing largely to the presence of one double bond at $\delta_{\mathrm{C}} 122.7(\mathrm{C}-3), 158.0(\mathrm{C}-4)$ and $175.4(\mathrm{C}-2)$ and the correlation in HMBC of the oxygenated methylene at $\delta_{\mathrm{H}} 4.97(\mathrm{H}-5)$ with $\mathrm{C}-2$ and $\mathrm{C}-4$.

The units but-1-ene-3,4-diol and $n$-pentenyl were connected to the lactone group by the correlation observed in $\mathrm{HMBC}$ of $\mathrm{H}-1$ ' with C-2 and C-4 and of $\mathrm{H}-\mathbf{1}^{\prime \prime}$ with C-4 and C-5, respectively, as depicted in Fig. 2.

Fig. 1. Compounds isolated from Camarops sp. 
Table 1

${ }^{1} \mathrm{H}$ - and ${ }^{13} \mathrm{C}$ NMR data for compounds $\mathbf{1 - 4}(600 \mathrm{MHz})$ in $\mathrm{CDCl}_{3}$.

\begin{tabular}{|c|c|c|c|c|c|c|c|c|c|c|}
\hline \multirow[b]{2}{*}{ Position } & \multicolumn{2}{|l|}{ Compound 1} & \multicolumn{2}{|l|}{ Compound 2} & \multirow[b]{2}{*}{ Position } & \multicolumn{3}{|l|}{ Compound 3} & \multicolumn{2}{|l|}{ Compound 4} \\
\hline & $\delta_{\mathrm{H}}(\mathrm{J}$ in $\mathrm{Hz})$ & $\delta_{\mathrm{C}}$ & $\delta_{\mathrm{H}}(\mathrm{J}$ in $\mathrm{Hz})$ & $\delta_{\mathrm{C}}$ & & $\delta_{\mathrm{H}}(\mathrm{J}$ in $\mathrm{Hz})$ & $\delta_{\mathrm{C}}$ & Position & $\delta_{\mathrm{H}}(J$ in $\mathrm{Hz})$ & $\delta_{\mathrm{C}}$ \\
\hline 1 & $1.92(d d d, 14.1 ; 7.0 ; 1.5)$ & 41.6 & $2.27(d, 11.5)$ & 58.8 & 2 & - & 175.4 & 1 & - & 172.7 \\
\hline 2 & $1.72(m)$ & 29.2 & $1.82(m)$ & 34.0 & 3 & - & 122.7 & 2 & - & 125.5 \\
\hline 3 & $3.30(d d, 11.2 ; 4.0)$ & 79.9 & $\begin{array}{l}1.09(\mathrm{~m}) \\
1.79(\mathrm{~m})\end{array}$ & 35.1 & 4 & - & 158.0 & 3 & $6.66(d q, 10.0 ; 1.2)$ & 150.9 \\
\hline 4 & - & 41.8 & $\begin{array}{l}1.74(\mathrm{~m}) \\
1.49(\mathrm{~m})\end{array}$ & 27.3 & 5 & $\begin{array}{l}4.97\left(d, \mathrm{~W}_{1 / 2} ; 16.0\right) \\
4.91\left(d, \mathrm{~W}_{1 / 2} ; 16.0\right)\end{array}$ & 70.2 & 4 & $2.33(\mathrm{~m})$ & 33.5 \\
\hline 5 & $3.38(d d, 9.5 ; 1.0)$ & 80.6 & $1.62(m)$ & 58.4 & $\mathbf{1}^{\prime}$ & $4.64(d, 5.0)$ & 69.3 & 5 & $1.31(m)$ & 36.6 \\
\hline 6 & - & 36.4 & - & 40.9 & $\mathbf{2}^{\prime}$ & $4.38(d d t, 5.5 ; 5.5 ; 1.5)$ & 74.9 & 6 & $1.24(m)$ & 29.8 \\
\hline 7 & $1.70(\mathrm{~m})$ & 40.7 & $\begin{array}{l}1.33(d, 12.5) \\
1.87(d, 12.5)\end{array}$ & 49.7 & $3^{\prime}$ & $5.82(d d d, 17.0 ; 10.5 ; 6.0)$ & 135.8 & 7 & $1.23(\mathrm{~m})$ & 29.9 \\
\hline 8 & 1.28 (brdd, 8.6; 8.6) & 47.7 & - & 44.4 & $4^{\prime}$ & $\begin{array}{l}5.33(d d d, 17.0 ; 3.0 ; 1.5) \\
5.20(d d d, 10.5 ; 3.0 ; 1.5)\end{array}$ & 117.6 & 8 & $1.25(\mathrm{~m})$ & 22.9 \\
\hline 9 & - & 72.8 & - & 83.2 & $\mathbf{1}^{\prime}$ & $6.59(d, 16.0)$ & 120.4 & 9 & $0.87(t, 7.0)$ & 14.1 \\
\hline 10 & $1.36(m)$ & 35.7 & - & 172.1 & $2^{\prime \prime}$ & $6.09(d t, 16.0 ; 7.0)$ & 142.2 & 10 & $1.82(s)$ & 12.3 \\
\hline 11 & $1.78(m)$ & 29.1 & $1.27(d, 6.0)$ & 22.7 & $3^{\prime \prime}$ & $2.20(d d d, 14.5 ; 7.5 ; 1.5)$ & 35.6 & 11 & $0.99(d, 6.5)$ & 20.0 \\
\hline 12 & $0.86(s)$ & 13.7 & $1.25(s)$ & 36.2 & $4^{\prime \prime}$ & $1.47(\mathrm{~m})$ & 21.8 & & & \\
\hline 13 & $0.92(s)$ & 24.4 & $1.13(s)$ & 27.7 & $5^{\prime \prime}$ & $0.92(t, 7.5)$ & 13.8 & & & \\
\hline 14 & $1.03(s)$ & 27.0 & $1.32(s)$ & 24.0 & 2 & - & 175.4 & & & \\
\hline 15 & & & $\begin{array}{l}4.75(d, 9.5) \\
3.90(d, 9.5)\end{array}$ & 78.0 & 3 & - & 122.7 & & & \\
\hline
\end{tabular}
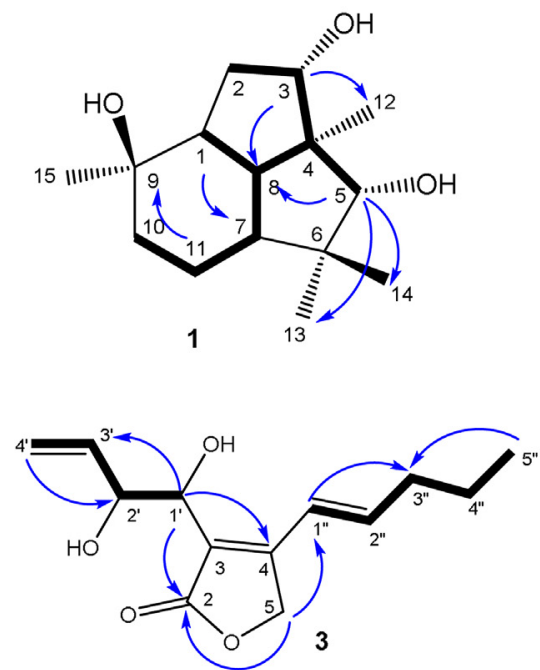
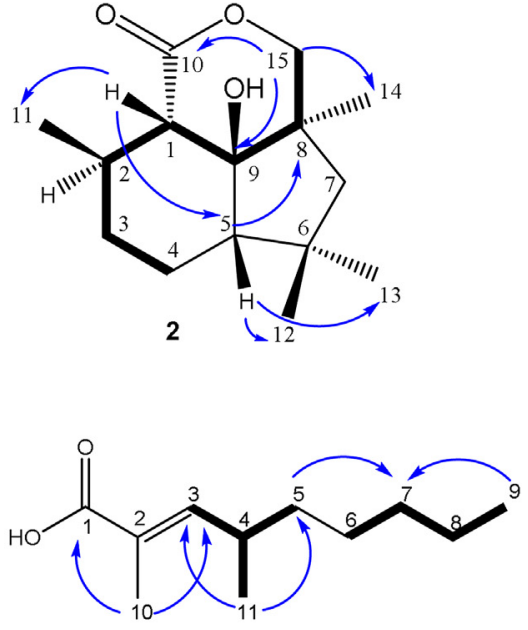

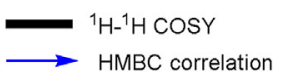

Fig. 2. $\mathrm{HMBC}$ and ${ }^{1} \mathrm{H}-{ }^{1} \mathrm{H}$ COSY correlations for 1-4.

The absolute stereochemistry at C-1' and C-2' was established through the application of the modified Mosher's ester method (Seco et al., 2004). Reaction of 3 with (R)-MPA and (S)-MPA separately yielded the bis-(S)- and bis-( $R$ )-Mosher esters (Fig. 3). Analysis of ${ }^{1} \mathrm{H}$ and ${ }^{13} \mathrm{C}$ chemical shift differences $\left(\Delta \delta_{S-R}\right)$ between 3a and 3b revealed negative $\Delta \delta_{S-R}$ values for $\mathrm{H}_{-} 4^{\prime}, \mathrm{H}-2^{\prime}$ and $\mathrm{H}-5$, and positive values for $\mathrm{H}-3^{\prime}, \mathrm{C}-2$ ', $\mathrm{H}-1^{\prime}, \mathrm{H}-5$ ', $\mathrm{H}-1^{\prime}$ and $\mathrm{C}-1^{\prime}$. These data led to the assignment of the absolute configurations at $\mathrm{C}-\mathbf{1}^{\prime}$ and $C-2$ ' of 3 as $S, S$. The structure of $\mathbf{3}$ was defined as $4-((E)$-pent-1enyl)-3-((1'S, 2'S)-1',2'-dihydroxybut-3-enyl)-5H-furan-2-one.

HRESIMS analysis of compound 4 showed a quasi-molecular ion peak $[2 \mathrm{M}]^{+}$at $\mathrm{m} / \mathrm{z} 368.0916$ corresponding to the formula $\mathrm{C}_{11} \mathrm{H}_{20} \mathrm{O}_{2}$, for which two degrees of unsaturation was assigned. As for the preceding compounds, IR (3371, 2358 and $1645 \mathrm{~cm}^{-1}$ ) and ${ }^{13} \mathrm{C}$ NMR spectra $\left(\delta_{\mathrm{C}} 172.7\right)$ indicated the presence of a carbonyl group.

Analysis of ${ }^{1} \mathrm{H},{ }^{13} \mathrm{C}$ and HSQC NMR spectra of $\mathbf{4}$ (Table 1) showed the presence of one $\mathrm{sp}^{2}$ methine, one $\mathrm{sp}^{3}$ methine, four methylene, and three methyl groups, with one methyl group attached to a double bond. The COSY and HMBC spectra indicated the presence of an $n$-pentyl moiety (Table 1 and Fig. 2). In the HMBC contour map, the vinylic proton $\mathrm{H}-3$ ( $\delta$ 6.66) showed correlations with $\mathrm{C}$ $10 / C-11$, and established the connectivity between $C-2$ to $C-3$ and $\mathrm{C}-3$ to $\mathrm{C}-4$. Again in $\mathrm{HMBC}, \mathrm{H}-10$ showed correlations with $\mathrm{C}-1$ and $\mathrm{C}-3$ and $\mathrm{H}-11$ with $\mathrm{C}-3$ and $\mathrm{C}-5$, indicating the chain branching points. The trans configuration for the double bond and the absolute configuration of compound $\mathbf{4}$ were determined through the comparison of its optical rotation, $[\alpha]^{26}{ }_{D}-0.4\left(c 0.1, \mathrm{CH}_{3} \mathrm{OH}\right)$, with that previously reported similarly for compound $5[\alpha]^{26}{ }_{D}+2.6$ (c 0.1, $\mathrm{CH}_{3} \mathrm{OH}$ ) (Rukachaisirikul et al., 2009; Alcaraz et al., 1999). These data allowed us to unambiguously establish the structure of 4 as $(2 E, 4 R)$-2,4-dimethylnon-2-enoic acid.

Compounds 5, 6 and $\mathbf{7}$ were identified as (2E,4S)-2,4dimethyloct-2-enoic acid, xylarenone $\mathrm{C}$ and xylarenone $\mathrm{D}$, respectively, based on the analysis of spectroscopic data and comparison with reports in the literature (Rukachaisirikul et al., 


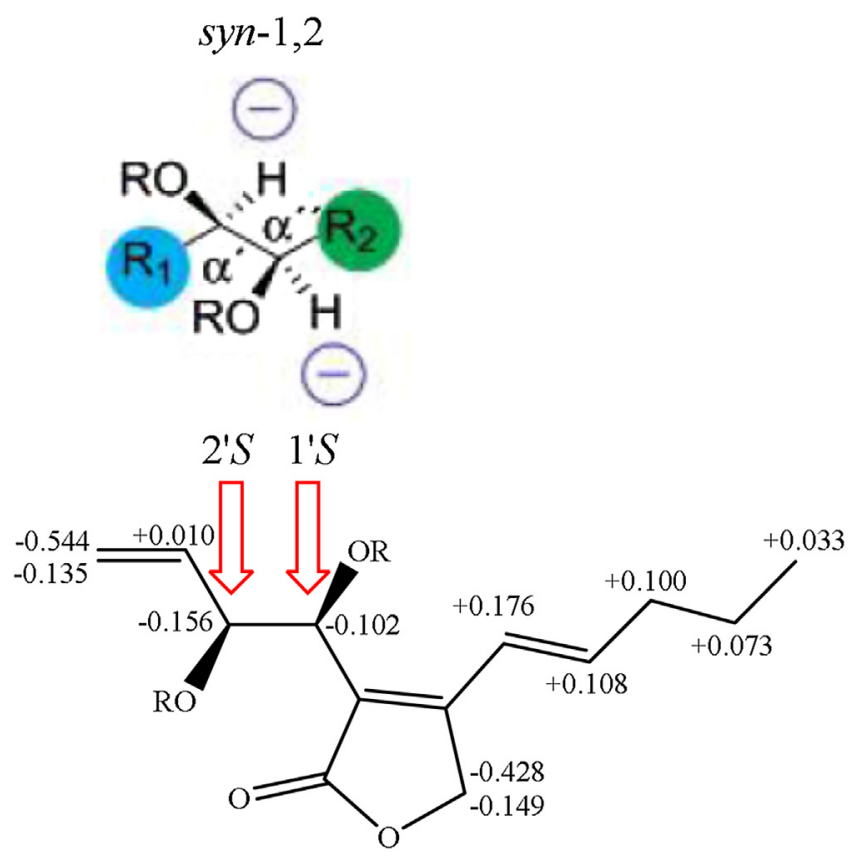

3a: $\mathbf{R}=(S)$-MTPA

3b: $\mathrm{R}=(R)-\mathrm{MTPA}$

Fig. 3. $\Delta \delta$ value $\left[(\Delta \delta\right.$ in ppm $\left.)=\delta_{S}-\delta_{R}\right]$ for 3 .

2009; Alcaraz et al., 1999; Yang et al., 2010; Zhang et al., 2012; Gubiani et al., 2014; Oliveira et al., 2011; Waalboer et al., 2009). The absolute configuration of compound $\mathbf{5}$ was identical to that of the known compound on the basis of their similar specific rotations (Rukachaisirikul et al., 2009; Alcaraz et al., 1999).

Compounds 3-7 were tested for their acetylcholinesterase (AChE) inhibitory activity using a bioautography assay and in vitro antiproliferative activity against human neoplasic cells. Preliminary TLC results suggested no acetylcholinesterase (AChE) inhibitory activity for compound $\mathbf{3}$ while weak activity was observed for compounds 4, 5 and 7. Compound $\mathbf{6}$ had a minimum AChE inhibitory concentration of $6.25 \mu \mathrm{g} / \mathrm{mL}$. Galantamine (positive control) was active at $1 \mu \mathrm{g} / \mathrm{mL}$. Compounds $\mathbf{6}$ and 7 exhibited in vitro antiproliferative activity against human neoplasic cells [leukemia (HL-60), melanoma (MDA/MB-435), colon (HCT-8) and
Table 2

In vitro cytotoxic activity determined using the MTT assay for xylarenones $\mathrm{C}(\mathbf{6})$ and $\mathrm{D}(7)$ in human tumor cell lines after $72 \mathrm{~h}$ of treatment.

\begin{tabular}{lllll}
\hline \multirow{2}{*}{ Compounds } & $\mathrm{IC}_{50}(\mu \mathrm{g} / \mathrm{mL})^{\mathrm{a}}$ & & & \\
\cline { 2 - 5 } & $\mathrm{HL}-60$ & $\mathrm{MDA} / \mathrm{MB}-435$ & $\mathrm{HCT}-8$ & $\mathrm{SF}-295$ \\
\hline $\mathbf{6}$ & 1.5 & 2.4 & 1.9 & 2.1 \\
\multirow{2}{*}{7} & $(1.3-1.9)$ & $(2.2-2.7)$ & $(1.8-2.1)$ & $(1.9-2.5)$ \\
\multirow{2}{*}{ Doxorubicin } & 1.2 & 2.1 & 1.5 & 1.9 \\
& $(0.9-1.6)$ & $(1.9-2.3)$ & $(1.3-1.6)$ & $(1.6-2.1)$ \\
& $(0.01-0.02)$ & $(0.3-0.7)$ & $(0.01-0.02)$ & $(0.2-0.3)$ \\
\hline
\end{tabular}

a Data are presented as $\mathrm{IC}_{50}$ values and $95 \%$ confidence intervals for leukemia (HL60), melanoma (MDA/MB-435), colon (HCT-8) and glioblastoma (SF-295) human cells. Doxorubicin was used as a positive control. Experiments were performed in duplicate.

glioblastoma (SF-295)] following $72 \mathrm{~h}$ of treatment (Table 2), with $\mathrm{IC}_{50}$ values of $2.4 \mu \mathrm{g} / \mathrm{mL}$ for 6 in MDA/MB-435 cells and $\mathrm{IC}_{50}$ of $1.2 \mu \mathrm{g} / \mathrm{mL}$ for 7 in HL-60 cells.

Compounds $\mathbf{4}$ and $\mathbf{5}$ presented weak AChE inhibitory activity. Compound $\mathbf{5}$ is found to be characterized by antibacterial activity as reported in the literature (Rukachaisirikul et al., 2009). Its homologues have been reported as constituents of the side chain of different metabolites, including xylarenal A and B (Waalboer et al., 2009), and xylarenones C, D, E, F and G (Gubiani et al., 2014; Oliveira et al., 2011). Xylarenones C, D, E, F and G were isolated in our previous work with the endophyte Camarops sp., and were found to possess potent antioxidant and anti-inflammatory activities besides exhibiting inhibitory activity of pepsin and subtilisin enzymes (Gubiani et al., 2014; Oliveira et al., 2011). The strong AChE inhibitory activity observed for compounds $\mathbf{6}$ and 7 implies that the side chain of these metabolites is related to their AChE inhibitory activity.

In conclusion, four new compounds and three known compounds from the culture media of the endophyte Camarops sp., associated with A. macrophylla, were isolated in this present investigation. Compounds $\mathbf{6}$ and $\mathbf{7}$ were found to exhibit micromolar in vitro antiproliferative activity against human neoplastic cells, while compounds $\mathbf{4 , 5}$ and $\mathbf{7}$ showed weak AChE inhibitory activities.

\section{Experimental}

\subsection{General experimental procedures}

${ }^{1} \mathrm{H}$ NMR (300 and $600 \mathrm{MHz}$ ), ${ }^{13} \mathrm{C}$ NMR (75 and $150 \mathrm{MHz}$ ), HMBC, HSQC and COSY experiments were recorded on a Bruker Fourier
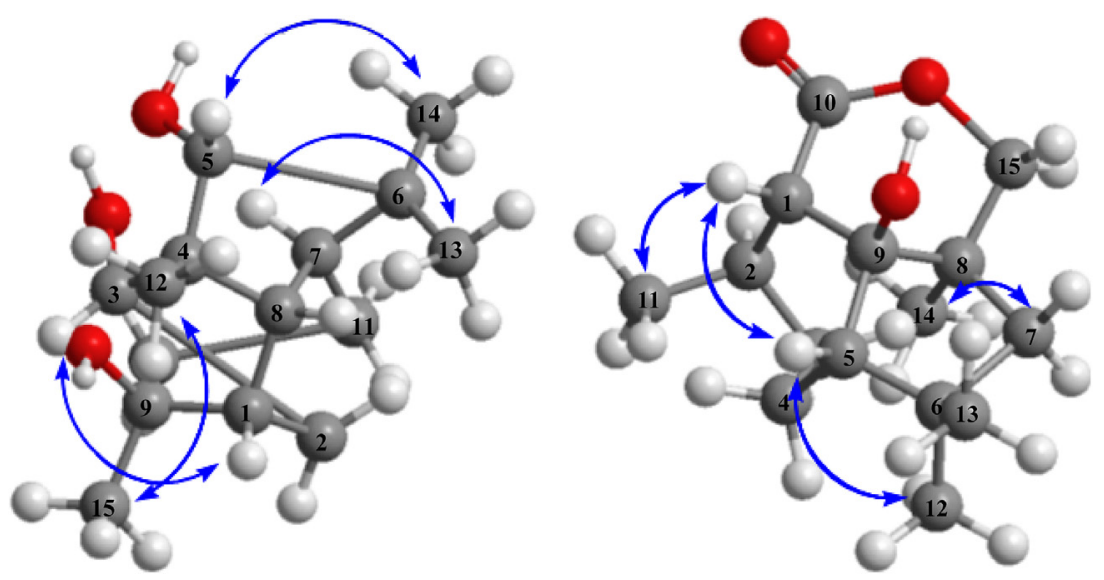

Fig. 4. NOE effects for $\mathbf{1}$ and $\mathbf{2}$. 
300 and Bruker Avance 600 spectrometer using the residual nondeuterated $\left(\mathrm{CDCl}_{3}\right)$ signal as an internal standard. Mass spectra were measured using a micrOTOF Q II Mass spectrometer set to ESI mode and using $\mathrm{MeOH}: \mathrm{H}_{2} \mathrm{O}(1: 1)$ as the solvent (cone voltage $25 \mathrm{~V}$ ). IR spectra were recorded on a Perkin-Elmer FTIR-1600 series spectrometer with the aid of $\mathrm{KBr}$ pellets and on a Bruker FTIRVERTEX 70 mode ATR using $\mathrm{MeOH}$ as the solvent. UV spectra were recorded on a Perkin Elmer Lambda 1050 UV/VIS/NIR spectrophotometer using $\mathrm{MeOH}$ as the solvent. Optical rotations were measured using a Perkin-Elmer polarimeter equipped with a sodium lamp operating at $28^{\circ} \mathrm{C}$ and a sample cell volume of $1 \mathrm{~mL}$ $(\mathrm{MeOH})$. TLC analyses were performed using Merck silica gel 60 (230 mesh) and precoated silica gel $60 \mathrm{PF}_{254}$. Spots on the TLC plates were visualized either under UV light or by spraying with anisaldehyde $-\mathrm{H}_{2} \mathrm{SO}_{4}$ reagent followed by heating at $120^{\circ} \mathrm{C}$. Preparative HPLC was performed by means of a Varian Prep-Star 400 system using a Phenomenex ${ }^{\circledR} C_{18}$ column $(250 \mathrm{~mm} \times 21.2$ $\mathrm{mm}$ ) preparative column. Analytical HPLC was performed using a Shimadzu SPD-M20A system with a Phenomenex Luna $C_{18}$ column $(250 \mathrm{~mm} \times 4.6 \mathrm{~mm})$. Column chromatography (CC) was performed over reversed-phase silica gel, 230-400 mesh (Merck).

\subsection{Fungal isolation and identification}

The endophytic fungus Camarops sp. was isolated from adult and healthy leaves of $A$. macrophylla, which were subjected to surface sterilization. The leaves were first washed with water and soap and then immersed in a $1 \%$ aqueous sodium hypochlorite solution for $5 \mathrm{~min}$, followed by $70 \%$ aqueous $\mathrm{EtOH}$ for $1 \mathrm{~min}$. After a second wash with $\mathrm{H}_{2} \mathrm{O}$ and soap, the leaves were subsequently immersed in sterile $\mathrm{H}_{2} \mathrm{O}$ for $10 \mathrm{~min}$. The sterilized leaves were cut into $2 \times 2 \mathrm{~cm}$ pieces and deposited into a Petri dish containing PDA (potato-dextrose agar) and anthramycin sulfate $(50 \mu \mathrm{g} / \mathrm{mL})$ with approximately 3 to 4 pieces per dish (Moore-Landecker, 1996). The pure fungal strain was obtained after serial transfers onto PDA and was stored as Camarops sp. at the NuBBE fungi collection in Araraquara, Brazil (kept in sterile water at $25^{\circ} \mathrm{C}$ ) (Silva et al., 2006). The pure Camarops sp. culture was sent to the Division of Microbial Resources, Multidisciplinary Center for Agricultural and Biological Chemistry Research - Divisão de Recursos Microbianos, Centro Pluridisciplinar de Pesquisas Químicas Biológicas e Agrícolas, State University of Campinas (CPQBA/UNICAMP), and was classified by Drs. Lara Durães Sette and André Rodrigues (Oliveira et al., 2011). The nucleotide sequence determined was deposited in the GenBank database under the access number GQ475287.

\subsection{Cultivation and Isolation of Metabolites of Camarops $s p$}

The endophytic fungus strain Camarops sp. was cultivated in 40 $500 \mathrm{~mL}$ Erlenmeyer flasks, each containing $90 \mathrm{~g}$ of corn and $80 \mathrm{~mL}$ of $\mathrm{H}_{2} \mathrm{O}$. The medium was autoclaved three times (in three consecutive days) at $121^{\circ} \mathrm{C}$ for $40 \mathrm{~min}$. Following sterilization, the medium was inoculated with the endophyte and incubated while stationary at $25^{\circ} \mathrm{C}$ for 21 days. At the end of the incubation period, the cultures were combined, ground and extracted with $\mathrm{CH}_{3} \mathrm{OH}(7 \times 350 \mathrm{~mL})$. The solvent was evaporated, yielding a crude $\mathrm{CH}_{3} \mathrm{OH}$ extract $(148.3 \mathrm{~g})$. The $\mathrm{CH}_{3} \mathrm{OH}$ extract was dissolved in $\mathrm{CH}_{3} \mathrm{CN}$ and defatted with hexane by liquid partitioning. The $\mathrm{CH}_{3} \mathrm{CN}$ fraction was evaporated to yield $17.2 \mathrm{~g}$ of crude extract. The crude $\mathrm{CH}_{3} \mathrm{CN}$ extract was fractioned by $\mathrm{C}_{18}$ RPCC and eluted with an $\mathrm{H}_{2} \mathrm{O}-\mathrm{CH}_{3} \mathrm{OH}$ gradient $(70: 30 \rightarrow 0: 100)$ and $\mathrm{CH}_{3} \mathrm{OH}-\mathrm{EtOAC}$ $(50: 50 \rightarrow 0: 100)$, generating eight fractions (Fr1-Fr8). Fraction Fr2 $(1.27 \mathrm{~g})$ was further fractioned using silica gel CC and eluted with a $\mathrm{CHCl}_{3}-\mathrm{CH}_{3} \mathrm{OH}$ gradient $(98: 2 \rightarrow 0: 100)$, giving rise to 15 subfractions (Fr2-A-Fr2-O). Subfractions Fr2-B to Fr2-D having similar TLC patterns were combined into one subfraction (Fr2-B) which was then purified using preparative thin layer chromatography (TLC) eluted with an $n$-hexane-EtOAc (60:40), generating five subfractions (Fr2-B1-Fr2-B5). Subfraction Fr2-B2 was identified as compound $3(56.1 \mathrm{mg})$. Fraction $\mathrm{Fr} 3(1.50 \mathrm{~g})$ was fractioned using $\mathrm{C}_{18}$ RPCC and eluted with an $\mathrm{H}_{2} \mathrm{O}-\mathrm{CH}_{3} \mathrm{OH}$ gradient $(90: 10 \rightarrow 0: 100)$ and $\mathrm{CH}_{3} \mathrm{OH}-\mathrm{EtOAc}(50: 50 \rightarrow 0: 100)$, giving rise to eleven fractions (Fr3-A-Fr3-K). Subfraction Fr3-D was identified as containing compound $\mathbf{1}(2.5 \mathrm{mg})$. Subfraction Fr3-F was fractioned using silica gel CC and eluted with an $n$-hexane-EtOAC gradient $(80: 20 \rightarrow 50: 50)$, resulting in six subfractions (Fr3-F1Fr3-F6). Subfraction Fr3-F2 was identified as containing compound $\mathbf{2}(7.8 \mathrm{mg}$ ) while subfraction Fr3-G was found to contain compound 4 (54.6 mg). Fraction Fr4 (2.50 g) was fractioned using $\mathrm{C}_{18}$ RPCC and eluted with an $\mathrm{H}_{2} \mathrm{O}-\mathrm{CH}_{3} \mathrm{OH}$ gradient $(85: 15 \rightarrow 0: 100)$ and $\mathrm{CH}_{3} \mathrm{OH}-\mathrm{EtOAC}(50: 50 \rightarrow 0: 100)$, leading to 13 fractions (Fr4-AFr4-M). Subfractions Fr4-F and Fr4-G having similar TLC patterns were combined into one subfraction ( $\mathrm{Fr} 4-\mathrm{F})$ and was identified as containing compound 5 (31.0 mg). Fraction Fr5 (1.72 g) was fractioned using silica gel CC and eluted with an $n$-hexane-EtOAc gradient (95:05 $\rightarrow$ 0:100), obtaining 14 subfractions ( Fr5-A-Fr5-N). Subfractions Fr5-E and Fr5-J were identified as containing compound 7 (67.2 $\mathrm{mg}$ ) and compound 6 (52.3 mg) respectively.

\subsubsection{3,5,9-trihydroxy presilphiperfolane (1)}

Yellow gum; $[\alpha]_{\mathrm{D}}^{26}-2.2\left(c 0.1, \mathrm{CH}_{3} \mathrm{OH}\right) ; \mathrm{UV}\left(\mathrm{CH}_{3} \mathrm{OH}\right) \lambda_{\max } \mathrm{nm}$ not observed; IR $\left(\mathrm{CH}_{3} \mathrm{OH}\right) \nu_{\max } 3375,2927 \mathrm{~cm}^{-1}$; HREIMS m/z: $531.3869[2 \mathrm{M}+\mathrm{Na}]^{+}$(calcd. for $\mathrm{C}_{30} \mathrm{H}_{52} \mathrm{O}_{6} \mathrm{Na}, 531.3664$ ); For the ${ }^{1} \mathrm{H}$ and ${ }^{13} \mathrm{C}$ NMR spectroscopic data, see Table 1.

\subsubsection{4-deoxy-10-oxodihydrobotrydial (2)}

Yellow gum; $[\alpha]^{26}{ }_{D}-26.2\left(c 0.1, \mathrm{CH}_{3} \mathrm{OH}\right) ; \mathrm{UV}\left(\mathrm{CH}_{3} \mathrm{OH}\right) \lambda_{\max } \mathrm{nm}$ 301; IR $\left(\mathrm{CH}_{3} \mathrm{OH}\right) \nu_{\max } 3408,1699,2933 \mathrm{~cm}^{-1}$; HREIMS $\mathrm{m} / z$ : 251.1623 [M-H] $]^{-}$(calcd. for $\mathrm{C}_{15} \mathrm{H}_{24} \mathrm{O}_{3}, 251.1648$ ); For the ${ }^{1} \mathrm{H}$ and ${ }^{13} \mathrm{C}$ NMR spectroscopic data, see Table 1.

\subsubsection{4-((E)-pent-1-enyl)-3-((1S,2S)-1,2-dihydroxybut-3-enyl)-5H- furan-2-one (3)}

Yellow gum; $[\alpha]^{23}{ }_{\mathrm{D}}-22.6\left(c \mathrm{c}, 1, \mathrm{CH}_{3} \mathrm{OH}\right) ; \mathrm{UV}\left(\mathrm{CH}_{3} \mathrm{OH}\right) \lambda_{\max } \mathrm{nm}$ 266; IR (KBr) $\nu_{\max } 3431,1735,2957 \mathrm{~cm}^{-1}$; HREIMS m/z: 261.1070 $[\mathrm{M}+\mathrm{Na}]^{+}$(calcd. for $\mathrm{C}_{13} \mathrm{H}_{18} \mathrm{O}_{4}, 261.1104$ ); For the ${ }^{1} \mathrm{H}$ and ${ }^{13} \mathrm{C}$ NMR spectroscopic data, see Table 1.

\subsection{4. (2E,4R)-2,4-dimethylnon-2-enoic acid (4)}

Yellow gum; $[\alpha]^{26}-0.4\left(c 0.1, \mathrm{CH}_{3} \mathrm{OH}\right) ; \mathrm{UV}\left(\mathrm{CH}_{3} \mathrm{OH}\right) \lambda_{\max } \mathrm{nm}$ not observed; IR $\left(\mathrm{CH}_{3} \mathrm{OH}\right) \nu_{\max } 3371,1645,2933,2358 \mathrm{~cm}^{-1}$. HREIMS $m / z$ : 367.2075 [2M-H] $]^{-}$(calcd. for $\mathrm{C}_{11} \mathrm{H}_{20} \mathrm{O}_{2}, 367.2850$ ); For the ${ }^{1} \mathrm{H}$ and ${ }^{13} \mathrm{C}$ NMR spectroscopic data, see Table 1.

\subsection{5. (2E,4S)-2,4-dimethyloct-2-enoic acid (5)}

Yellow gum; $[\alpha]^{26}{ }_{\mathrm{D}}+2.6\left(c \mathrm{0.1}, \mathrm{CH}_{3} \mathrm{OH}\right) ; \mathrm{UV}\left(\mathrm{CH}_{3} \mathrm{OH}\right) \lambda_{\max } \mathrm{nm}$ not observed; IR $\left(\mathrm{CH}_{3} \mathrm{OH}\right) v_{\max } 3303,1641,2364 \mathrm{~cm}^{-1}$. The ${ }^{1} \mathrm{H}$ and ${ }^{13} \mathrm{C}$ NMR spectroscopic data were found to be consistent with $\mathrm{t}$ those reported in the literature (Rukachaisirikul et al., 2009; Alcaraz et al., 1999; Yang et al., 2010).

\subsubsection{Xylarenone $C(\mathbf{6})$}

Yellow gum; $[\alpha]^{24}{ }_{\mathrm{D}}+1,5\left(c \mathrm{0}, 1, \mathrm{CH}_{3} \mathrm{OH}\right) ; \mathrm{UV}\left(\mathrm{CH}_{3} \mathrm{OH}\right) \lambda_{\max } \mathrm{nm}$ 240; IR (KBr) $\nu_{\max } 3464,1734,1618 \mathrm{~cm}^{-1}$. The ${ }^{1} \mathrm{H}$ and ${ }^{13} \mathrm{C}$ NMR spectroscopic data were found to be consistent with those reported in the literature (Oliveira et al., 2011).

\subsubsection{Xylarenone $D(7)$}

Yellow gum, $[\alpha]^{24}+43,2\left(c 0,1, \mathrm{CH}_{3} \mathrm{OH}\right)$. UV $\left(\mathrm{CH}_{3} \mathrm{OH}\right) \lambda_{\max } \mathrm{nm}$ 234; IR (KBr) $\nu_{\max } 3448,1734,1677 \mathrm{~cm}^{-1}$. The ${ }^{1} \mathrm{H}$ and ${ }^{13} \mathrm{C}$ NMR spectroscopic data were found to be consistent with those reported in the literature (Oliveira et al., 2011). 
3.3.8. Preparation of $(S)$ - and (R)-MPA ester derivatives of compound 3

The 2-furanone derivative was esterified with $(R)$ - and $(S)$ $\alpha$-methoxyphenylacetic acid (MPA). The solution of 2 -furanone (1 equiv) in the presence of 1-ethyl-3-[3-(dimethylamin)propyl] carbodiimide (EDC) (1 equiv for each hydroxyl group) and 4dimethylaminpyridine (DMAP) catalyzed in dried dichloromethane under an atmosphere of $\mathrm{N}_{2}$ was added to the solution of MPA ( 1 equiv for each hydroxyl group). The mixture was stirred within 3-8 hours. Afterwards, the organic phase was washed with a

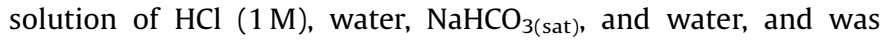
subsequently dried with $\mathrm{Na}_{2} \mathrm{SO}_{4}$ and concentrated in an rotative evaporator (Freire et al., 2007). The compounds were characterized by NMR (1D and 2D). (S)-MPA ester derivative 3a. ${ }^{1} \mathrm{H}$ NMR data of 3a: $\left(600 \mathrm{MHz}, \mathrm{CDCl}_{3}\right) . \delta 6.597(1 \mathrm{H}, d, J=16.0 \mathrm{~Hz}, \mathrm{H}-1 "), 6.061(1 \mathrm{H}$, $\left.d t, J=16.0,7.0 \mathrm{~Hz}, \mathrm{H}-2^{\prime \prime}\right), 5.804\left(1 \mathrm{H}, d, J=7.0 \mathrm{~Hz}, \mathrm{H}-1^{\prime}\right), 5.584(1 \mathrm{H}$, $\left.d d t, J=6.5,1.0 \mathrm{~Hz}, \mathrm{H}-2^{\prime}\right), 5.404\left(1 \mathrm{H}, d d d, J=17.0,10.5,6.5 \mathrm{~Hz}, \mathrm{H}-3^{\prime}\right)$, $4.823(1 \mathrm{H}, d d d, J=10.5,3.0,1.0 \mathrm{~Hz}, \mathrm{H}-4 \mathrm{a}), 4.764$ (1H, s, H-5a), 4.696 $\left(1 \mathrm{H}, d d d, J=17.0,1.0 \mathrm{~Hz}, \mathrm{H}-4 \mathrm{~b}^{\prime}\right), 4.577(1 \mathrm{H}, \mathrm{s}, \mathrm{H}-5 \mathrm{~b}), 2.234(2 \mathrm{H}, d d d$, $J=14.5,7.5,1.5 \mathrm{~Hz}, \mathrm{H}-3 "), 1.519$ (2H, $m, \mathrm{H}-4 "), 0.984(3 \mathrm{H}, t, J=7.5 \mathrm{~Hz}$, H-5"). ${ }^{13}$ C NMR data of 3a: $\delta 171.0$ (C-2), 126.8 (C-3), 159.7 (C-4), 82.2 (C-5), 68.5 (C-1'), 74.0 (C-2'), 130.5 (C-3'), 120.3 (C-4'), 120.6 (C-1"), 144.6 (C-2"), 35.7 (C-3"), 22.2 (C-4"), 14.3 (C-5"). (R)-MPA ester derivative $\mathbf{3 b} .{ }^{1} \mathrm{H}$ NMR data of $\mathbf{3 b}$ : $\left(600 \mathrm{MHz}, \mathrm{CDCl}_{3}\right) . \delta 6.421$ $(1 \mathrm{H}, d, J=16.0 \mathrm{~Hz}, \mathrm{H}-1 "), 5.953(1 \mathrm{H}, d t, J=16.0,7.0 \mathrm{~Hz}, \mathrm{H}-2 "), 5.906$ $\left(1 \mathrm{H}, d d d, J=17.0,10.5,6.5 \mathrm{~Hz}, \mathrm{H}-3{ }^{\prime}\right), 5.740\left(1 \mathrm{H}, d, J=6.0 \mathrm{~Hz}, \mathrm{H}-1^{\prime}\right)$, $5.394(1 \mathrm{H}, d d d, J=10.5,1.0 \mathrm{~Hz}, \mathrm{H}-4 \mathrm{a}), 5.367(1 \mathrm{H}, d d t, J=6.5,1.0 \mathrm{~Hz}$, $\left.\mathrm{H}^{2} 2^{\prime}\right), 5.192\left(1 \mathrm{H}, d d d, J=17.0,3.0,1.0 \mathrm{~Hz}, \mathrm{H}-4 \mathrm{~b}^{\prime}\right), 4.831(1 \mathrm{H}, s, \mathrm{H}-5 \mathrm{a})$, 4.726 (1H, s, H-5b), 2.134 (2H, ddd, $J=14.5,7.5,1.5 \mathrm{~Hz}, \mathrm{H}-3 "), 1.446$ (2H, m, H-4"), 0.951 (3H, $t, J=7.5 \mathrm{~Hz}, \mathrm{H}-5 ") .{ }^{13} \mathrm{C}$ NMR data of $\mathbf{3 b}: \delta$ 173.9 (C-2), 127.4 (C-3), 160.1 (C-4), 82.8 (C-5), 70.2 (C-1'), 77.3 (C$\left.2^{\prime}\right), 132.4\left(\mathrm{C}-3^{\prime}\right), 118.2$ (C-4'), 120.4 (C-1"), 142.3 (C-2"), 35.8 (C-3"), 22.0 (C-4"), 13.9 (C-5").

\subsection{Acetylcholinesterase inhibitory activity}

The ability of the pure compounds to inhibit AChE was determined using a TLC bioautographic assay as described previously (Marston et al., 2002). Compounds 4-7 were applied on TLC layers in the concentration range of 0.1 to $6.0 \mu \mathrm{g} / \mathrm{mL}$, followed by elution with $n$-hexane-EtOAc $(9: 1, \mathrm{v} / \mathrm{v})$ and subsequent drying. The plates were then sprayed with enzyme solution $\left(6.66 \mathrm{U} / \mathrm{mL}\right.$ ), thoroughly dried and incubated at $37^{\circ} \mathrm{C}$ for $20 \mathrm{~min}$ (in a moist atmosphere). Enzyme activity was detected by spraying with a solution consisting of $0.25 \%$ 1-naphthyl acetate in $\mathrm{CH}_{3} \mathrm{CH}_{2} \mathrm{OH}$ containing $0.25 \%$ Fast Blue B salt (in aqueous solution). Potential acetylcholinesterase inhibitors appeared as clear zones on a purple-colored background. Electric eel AChE type V (product no. $C 2888,1000 \mathrm{U}$ ) and the other reagents were purchased from Sigma-Aldrich.

\subsection{MTT assay}

The cytotoxicity of compounds $\mathbf{6}$ and $\mathbf{7}$ was evaluated using the MTT assay (Skehan et al., 1990) against four human cancer cell lines - HL-60 (leukemia), HCT-8 (colon), MDA/MB-435 (melanoma) and SF-295 (glioblastoma) - all of which were obtained from the National Cancer Institute (NCI, Bethesda, MD, USA). Cell lines were maintained in RPMI 1640 medium supplemented with 10\% fetal bovine serum, $2 \mathrm{mM}$ glutamine, $100 \mathrm{U} / \mathrm{mL}$ penicillin and $100 \mu \mathrm{g} / \mathrm{mL}$ streptomycin at $37^{\circ} \mathrm{C}$ under $5 \% \quad \mathrm{CO}_{2}$. Tumor cell proliferation was quantified indirectly based on the ability of living cells to reduce the yellow dye 3-(4,5-dimethyl-2-thiazolyl)2,5-diphenyl-2H-tetrazolium bromide (MTT) to a purple formazan product (Mosmann, 1983). Briefly, cells were plated into 96-well plates, and the compounds $(0.02-25 \mu \mathrm{g} / \mathrm{mL})$ were added to the wells. Following $69 \mathrm{~h}$ of incubation, the supernatant was replaced by fresh medium containing MTT $10 \%$. Three hours later, the MTT formazan product was dissolved in $150 \mu \mathrm{L}$ DMSO and the absorbance was measured at $595 \mathrm{~nm}$ (DTX-880, Beckman Coulter). Doxorubicin (Dox, Sigma-Aldrich) was used as a positive control $(0.009$ to $5 \mu \mathrm{g} / \mathrm{mL})$. The $\mathrm{IC}_{50}$ values and $95 \%$ confidence intervals were obtained by nonlinear regression using the GraphPad program (Intuitive Software for Science, San Diego, CA) (Ferreira et al., 2011).

\section{Supporting Information}

Selected ${ }^{1} \mathrm{H}$ and ${ }^{13} \mathrm{C}$ NMR, ${ }^{1} \mathrm{H}-{ }^{1} \mathrm{H}$ COSY, HSQC, and HMBC spectra of compounds $1,2,3$ and 4 . Selected NOEs observed in the NOESY$1 \mathrm{D}$ experiments of compounds $\mathbf{1}$ and $\mathbf{2}$. Mass spectra of compounds $\mathbf{1}, \mathbf{2}, \mathbf{3}$ and $\mathbf{4}$ can be found, in the online version, at doi: $10.1016 / \mathrm{j}$. phytol.2016.08.007.

\section{Acknowledgement}

The authors thank the Brazilian funding agencies - Fundação de Amparo à Pesquisa do Estado de São Paulo (FAPESP - grant process \# 2013/07600-3) and CNPq (process \# 563286/2010-5) for the funds provided in the course of this research. JRG, CRN, MDPP and PMPF are extremely grateful to CNPq and CAPES for granting them Ph.D. scholarships. Our thanks also go to Brian Newmann the native English language content editor for his painstaking proofreading and editing of the manuscript.

\section{References}

Alcaraz, L., Macdonald, G., Ragot, J., Lewis, N.J., Taylor, R.J.K., 1999. Synthetic approaches to the manumycin A, B and C antibiotics: the first total synthesis of (+)-Manumycin A. Tetrahedron 55, 3707-3716.

Ali, Y., Alam, M.S., Hamid, H., Husain, A., Dhulap, A., Bano, S., Kharbanda, C., Nazreen, S., Haider, S., 2015. Design and synthesis of butenolide-based amide derivatives s anti-inflammatory agents. Med. Chem. Res. 24, 3775-3784.

Collado, I.G., Sánchez, A.J.M., Hanson, J.R., 2007. Fungal terpene metabolites: biosynthetic relationships and the control of the phytopathogenic fungus Botrytis cinerea. Nat. Prod. Rep. 24, 674-686.

Collado, I.G., Hernández-Galán, R., Durán-Patrón, R., Cantoral, J.M., 1995. Metabolites from a shake culture of Botrytis cinerea. Phytochemistry 38, 647 650.

Daoubi, M., Durán-Patrón, R., Hernández-Galán, R., Benharref, A., Hanson, J.R., Collado, I.G., 2006. The role of botrydienediol in the biodegradation of the sesquiterpenoid phytotoxin botrydial by Botrytis cinerea. Tetrahedron 62, 82568261.

Durán-Patrón, R., Colmenares, A.J., Hernández-Galán, R., Collado, I.G., 2001. Some key metabolic intermediates in the biosynthesis of botrydial and related compound. Tetrahedron 57, 1929-1933.

Ferreira, P.M.P., Farias, D.F., Viana, M.P., Souza, T.M., Vasconcelos, I.M., Soares, B.M. Pessoa, C., Costa-Lotufo, L.V., Moraes, M.O., Carvalho, A.F.U., 2011. Study of the antiproliferative potential of seed extracts from Northeastern Brazilian plants. An. Acad. Bras, Cienc. 3, 1045-1058.

Freire, F., Seco, J.M., Quiñoá, E., Riguera, R., 2007. Challenging the absence of observable hydrogens in the assignment of absolute configurations by NMR: application to chiral primary alcohols. Chem. Commun. 14, 1456-1458.

Gubiani, J.R., Zeraik, M.L., Oliveira, C.M., Ximenes, V.F., Nogueira, C.R., Fonseca, L.M. Silva, D.H.S., Bolzani, V.S., Araujo, A.R., 2014. Biologically active eremophilanetype sesquiterpenes from Camarops sp.: an endophytic fungus isolated from Alibertia macrophylla. J. Nat. Prod. 77, 668-672.

Mao, W., Zhu, C., 2015. Synergistic acid-promoted synthesis of highly substituted butenolides via the annulation of keto acids and tertiary alcohols. Org. Lett. 17, 5710-5713.

Marston, A., Kissling, J., Hostettmann, K., 2002. A rapid TLC bioautographic method for the detection of acetylcholinesterase and butyrylcholinesterase inhibitors in plants. Phytoch. Anal. 13, 51-54.

Moore-Landecker, E., 1996. Fundamentals of the Fungi, fourth ed. Prentice Hall, New Jersey.

Mosmann, T., 1983. Rapid colorimetric assay for cellular growth and survival: application to proliferation and cytotoxicity assays. J. Immunol. Methods 65, $55-63$.

Oliveira, C.M., Silva, G.H., Regasini, L.O., Flausino, O., López, S.N., Abissi, B.M., Berlinck, R.G.S., Sette, L.D., Bonugli-Santos, R.C., Rodrigues, A., Bolzani, V.S., Araujo, A.R., 2011. Xylarenones C-E from an endophytic fungus isolated from Alibertia macrophylla. J. Nat. Prod. 74, 1353-1357. 
Reino, J.L., Durán-Patrón, R., Segura, I., Hernández-Galán, R., Riese, H.H., Collado, I.G., 2003. Chemical transformations on botryane skeleton. Effect on the cytotoxic activity. J. Nat. Prod. 66, 344-349.

Rukachaisirikul, V., Khamthong, N., Sukpondma, Y., Pakawatchai, C., Phongpaichit, S., Sakayaroj, J., Kirtikara, K., 2009. An cytochalasin, cytochalasin derivative from the marine-derived fungus Xylaria sp. PSU-F100. Chem. Pharm. Bull. 57, 14091411.

Seco, J.M., Quiñoá, E., Riguera, R., 2004. The assignment of absolute configuration by NMR. Chemical Reviews 104, 17-117.

Silva, G.H., Teles, H.L., Zanardi, L.M., Young, M.C.M., Eberlin, M.N., Haddad, R., Pfenning, L.H., Costa-Neto, C., Castro-Gamboa, I., Bolzani, V.S., Araujo, A.R., 2006. Cadinane sesquiterpenoids of Phomopsis cassiae, an endophytic fungus associated with Cassia spectabilis (Leguminosae). Phytochemistry 67, 19641969.
Skehan, P., Storeng, R., Scudiero, D., Monks, A., Mcmahon, J., Vistica, D., Warren, J.T., Bodesch, H., Kenney, S., Boyd, M.R., 1990. New colorimetric cytotoxicity assay for anticancer -drug screening. J. Natl. Cancer Inst. 82, 1107-1112.

Waalboer, D.C.J., van Kalkeren, H.A., Schaapman, M.C., van Delft, F.L., Rutjes, F.P.J.T. 2009. Total synthesis and absolute stereochemistry of integric acid. J. Org. Chem. 74, 8878-8881.

Yang, M.C., Kwon, H.C., Kim, Y.-J., Lee, K.R., Yang, H.O., 2010. Oploxynes A and B, polyacetylenes from the stems of Oplopanax elatus. J. Nat. Prod. 73, 801-805.

Yuan, L., Ma, J., Wang, T., Li, G.-H., Shen, Y.-M., Zhao, P.-J., 2009. Chemical constituents from endophytic Phomopsis sp: Lz42 of Maytenus hookeri. Chem. Res. Chin. Univ. 30, 78-81.

Zhang, F., Li, L., Niu, S., Si, Y., Guo, L., Jiang, X., Che, Y., 2012. A Thiopyranchromenone and other chromone derivatives from an endolichenic fungus, Preussia africana. J. Nat. Prod. 75, 230-237. 